\title{
Improving management of glycaemic control in people with T2DM in primary care: estimation of the impact on the clinical complications and associated costs
}

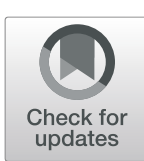

M. Mata-Cases ${ }^{1 *}$ D, J. Mahon², D. Mauricio ${ }^{1}$, J. Franch-Nadal ${ }^{1}$, J. Real ${ }^{1}$ and N. Hex ${ }^{2}$

\begin{abstract}
Background: To estimate the potential benefits in terms of avoided complications and cost reduction if the Spanish health system would encourage the intensification of treatment for better glycaemic control in adults with Type 2 diabetes from the current $\mathrm{HbA} 1 \mathrm{c}$ target used in clinical practice of $68 \mathrm{mmol} / \mathrm{mol}$ to a target of $53 \mathrm{mmol} / \mathrm{mol}$.

Methods: The IQVIA Core Diabetes Model (version 9.0) was used to model the impact of these changes in respect of micro- and macrovascular complications and the associated costs. The modelling was based on data derived from the SIDIAP-Q population database from Catalonia, taking a random cohort of 10,000 people with type 2 diabetes and dividing it into sub-groups based on their baseline HbA1c.

Results: The CDM modelling showed that the average cost reduction per person varies depending on baseline HbA1c. The model estimates that after 25 years, people with a baseline HbA1c between 48 and $58 \mathrm{mmol} / \mathrm{mol}$ and $>75 \mathrm{mmol} /$ mol show an average cost reduction of $€ 6027$ and $€ 11,966$, respectively. Applying the per-person cost reduction to the cohorts of the prevalent population in Spain $(1,910,374)$ the overall estimated cost reduction was $€ 14.7$ billion over 25 years. The improvements in outcomes resulted in an estimated reduction of more than 1.2 million complications cumulatively over 25 years, of which more than 550,000 relate to diabetic foot and more than 170,000 related to renal disease.

Conclusion: Over a 25 year period, Spain could considerably reduce costs and avoid major complications if, on a population level, more ambitious glycaemic control, according to Spanish or EU guidelines, could be achieved among people with type 2 diabetes by reducing the $\mathrm{HbA1c}$ threshold for treatment intensification. Although there is a slower trajectory for benefits in earlier years, there is a much more rapid benefit gain between years 5 and 15.
\end{abstract}

Keywords: Type 2 diabetes, Health economics, Diabetes complications, Glycaemic control

\footnotetext{
* Correspondence: manelmatacases@gmail.com

'DAP-Cat group, Unitat de Suport a la Recerca Barcelona Ciutat, Institut Universitari d'Investigació en Atenció Primària Jordi Gol (IDIAP Jordi Gol), CIBER of Diabetes and Associated Metabolic Diseases (CIBERDEM), Instituto de Salud Carlos III (ISCIII), Carrer Sardenya 375, entlo 1a, 08025 Barcelona, Spain

Full list of author information is available at the end of the article
}

(C) The Author(s). 2020 Open Access This article is licensed under a Creative Commons Attribution 4.0 International License, which permits use, sharing, adaptation, distribution and reproduction in any medium or format, as long as you give appropriate credit to the original author(s) and the source, provide a link to the Creative Commons licence, and indicate if changes were made. The images or other third party material in this article are included in the article's Creative Commons licence, unless indicated otherwise in a credit line to the material. If material is not included in the article's Creative Commons licence and your intended use is not permitted by statutory regulation or exceeds the permitted use, you will need to obtain permission directly from the copyright holder. To view a copy of this licence, visit http://creativecommons.org/licenses/by/4.0/. The Creative Commons Public Domain Dedication waiver (http://creativecommons.org/publicdomain/zero/1.0/) applies to the data made available in this article, unless otherwise stated in a credit line to the data. 


\section{Background}

Type 2 diabetes incurs a very high cost burden for health care systems and individual organizations, both in relation management of the disease and its associated complications [1-4]. This is the case for both primary and specialist care organizations and is especially pertinent in countries with a National Health System, which are generally encountering significant financial pressures. Some studies have shown that the healthcare costs of people with diabetes can be 60 to $80 \%$ higher than for people without diabetes [2-4]. Much of this additional cost burden can be accounted for by late complications such as end stage renal disease (ESRD), which because it requires dialysis and transplantation, can result in more significant cost increases than those relating to, for example, cardiovascular disease $[1,5]$. Complications such as ESRD also have a more significant impact on morbidity and mortality $[1,5]$.

Glycaemic control statistics show that in Spain, although population-wide diabetes management is acceptable or similar to other countries, it could be improved [6-8]. In general, intensification of Type 2 diabetes treatment is often delayed resulting in poor control and increased risk of costly and preventable complications. As in other countries, current evidence is that the mean HbA1c level of treatment intensification is higher than clinically recommended. According to four different studies, treatment intensification in Spain, was made around $68 \mathrm{mmol} / \mathrm{mol}$ [710]. In 2011, the way $\mathrm{HbA1c}$ values were reported switched from a percentage to a measurement in millimoles per mole (mmols $/ \mathrm{mol}$ ). $68 \mathrm{mmol} / \mathrm{mol}$ equates to $8.4 \%$ and $53 \mathrm{mmol} / \mathrm{mol}$ equates to $7.0 \%$.

The clinical practice guideline for the Spanish $\mathrm{Na}$ tional Health System (NHS) on type 2 diabetes states that whilst individual patient clinical needs and preferences should be taken into account, a target of 53 $\mathrm{mmol} / \mathrm{mol}$ for HbA1c should be considered desirable with treatment adjusted accordingly [11]. This is in accordance with the European Society of Cardiology Guidelines on HbA1c targets [12]. If diet and exercise should fail to keep HbA1c to the target then the treatment algorithm in the guideline recommends to start a patient on monotherapy, then to progress to a combination therapy (dual or triple) and finally to insulin. Treatment intensification should be considered when the HbA1c target of $53 \mathrm{mmol} / \mathrm{mol}$ is not being achieved. Nevertheless, in Spain, studies conducted in primary care reported that the lack of intensification in people with diabetes with poor glycemic control (HbA1c $\geq 53 \mathrm{mmol} / \mathrm{mol}$ ) varies between 32.2 and $52.5 \%[7,13,14]$. The longest delays in treatment intensification are known to occur among people with diabetes on two or more non-insulin anti-diabetic drugs $[10,14,15]$.
The glycated hemoglobin (HbA1c) value at which treatment intensification is recommended varies between $48 \mathrm{mmol} / \mathrm{mol}$ and $64 \mathrm{mmol} / \mathrm{mol}$ in international and national guidelines, and it is $64 \mathrm{mmol} / \mathrm{mol}$ for incentivization purposes in our institution (Catalan Institute of Health; ICS) [16]. This national threshold is based on the idea that people with HbA1c levels above $64 \mathrm{mmol} /$ mol are the most likely to benefit from a timely intensification and to avoid overtreatment in the elderly, but the evidence on the cost-effectiveness of this approach is scarce.

Baxter et al. (2016) reported that in the UK, improvements in glycaemic control led to an average reduction and delay in the onset of all diabetes-related complications and mortality rates [17]. The cumulative cost reduction for the UK health system over 25 years was estimated at almost $£ 5$ billion for Type 2 diabetes if people with diabetes receive treatment escalations according to the National Institute of Health and Care Excellence (NICE) Type 2 diabetes treatment algorithm [18].

The aim of this study was to use a similar approach to that used by Baxter et al. to estimate the effect of improvements in glycaemic control on the cumulative rate of type 2 diabetes complications in Spain and the associated costs. Specifically, the main objective was to examine the impact of intensifying treatment to better control HbA1c at the target of $53 \mathrm{mmol} / \mathrm{mol}$, instead of the current mean HbA1c level of treatment intensification $(68 \mathrm{mmol} / \mathrm{mol})$. The study does not incorporate any costs related to interventions that could be used to intensify treatment because it is for individual health commissioners and providers to determine the interventions they wish to invest in to improve glycaemic control in people with Type 2 diabetes and care should be individualised for each person. The purpose of the study is to highlight the potential that might be available for investment in diabetes care models and programmes rather than to demonstrate the outcome of a specific intervention or set of interventions.

\section{Methods}

Modelling simulations were carried out to examine the impact of intensifying treatment to better control HbA1c at the target of $53 \mathrm{mmol} / \mathrm{mol}$, instead of the current mean HbA1c level of treatment intensification (68 $\mathrm{mmol} / \mathrm{mol}$ ). Clinical guidelines, such as the Spanish clinical practice guideline for diabetes and the ESC guideline $[11,12]$, suggest treatment algorithms that aim to maintain HbA1c at or below target levels in order to achieve optimal outcomes for people with diabetes.

The IQVIA Core Diabetes Model (CDM) is able to run patient-level modelling simulations in this way. The CDM is a widely published and validated $[19,20]$ model for Type 1 and Type 2 diabetes. It is a non-product 
Table 1 Management and complication costs used in the CDM

\begin{tabular}{|c|}
\hline Management costs \\
\hline Statins (Atorvastina 20 MG 28 comprimidos) \\
\hline Aspirin (Adiro 100 mg 30 comprimidos) \\
\hline ACE inhibitor (Enalapril 20 MG 28 comprimid \\
\hline Annual Screening for microalbuminurea \\
\hline Annual screening gross renal protenuira \\
\hline Stopping ACEs due to side effects \\
\hline Annual eye screening \\
\hline Foot screening program \\
\hline Non-standard ulcer treat (eg. Regranex) \\
\hline Anti-depression treatment \\
\hline Screening for depression \\
\hline Direct costs CVD complications \\
\hline Myocardial infarction 1st year average \\
\hline Myocardial infarction 1st year fatal \\
\hline Myocardial infarction 1st year non-fatal \\
\hline Myocardial infarction 2 nd + years \\
\hline Angina 1st year \\
\hline Angina $2 \mathrm{nd}+$ years \\
\hline Congestive heart failure 1st year average \\
\hline Congestive heart failure 1st year fatal \\
\hline Congestive heart failure 1st year non-fatal \\
\hline Congestive heart failure 2 nd plus years \\
\hline Stroke 1st year non-fatal \\
\hline Stroke $2 \mathrm{nd}+$ years \\
\hline Stroke death within 30 days \\
\hline Peripheral vascular disease 1st year \\
\hline Peripheral vascular disease $2 \mathrm{nd}+$ years \\
\hline
\end{tabular}

\section{Direct costs renal complications}

Haemodialysis 1st year

Haemodialysis $2+$ years

Peritoneal dialysis 1st year

Peritoneal dialysis 2+ years

Renal transplant costs 1st year

Renal transplant $2+$ years

\section{Direct costs acute events}

Major hypoglycaemic event

Minor hypoglycaemic event

Lactic acid event

Edema onset (adverse event)

Edema follow-up (adverse event)

\section{Direct costs acute events}

Laser treatment

Cataract operation

Following cataract operation

\begin{tabular}{|c|c|}
\hline Cost $(€)$ & Source \\
\hline 120.14 & https://botplusweb.portalfarma.com/botplus.aspx Botplus 2015 \\
\hline 88.27 & https://botplusweb.portalfarma.com/botplus.aspx Botplus 2015 \\
\hline 21.00 & https://botplusweb.portalfarma.com/botplus.aspx Botplus 2015 \\
\hline 50.83 & eSalud 2015 (official tariff) \\
\hline 203.44 & eSalud 2015 (official tariff) \\
\hline 54.08 & [21] Fonseca 2013 \\
\hline 55.27 & eSalud 2015 (official tariff) \\
\hline 23.69 & eSalud 2015 (official tariff) \\
\hline \multicolumn{2}{|l|}{-} \\
\hline 288.05 & [22] Salvador-Carulla 2009 \\
\hline- & eSalud 2015 (official tariff) \\
\hline Cost $(€)$ & Source \\
\hline 5282.63 & [23] Abad 2015 \\
\hline 4566.21 & [23] Abad 2015 \\
\hline 5383.13 & [23] Abad 2015 \\
\hline 860.43 & [23] Abad 2015 \\
\hline 2373.60 & [23] Abad 2015 \\
\hline 860.43 & [23] Abad 2015 \\
\hline 3564.34 & [23] Abad 2015 \\
\hline 4566.21 & [23] Abad 2015 \\
\hline 3505.02 & [23] Abad 2015 \\
\hline 3554.47 & [23] Abad 2015 \\
\hline 6658.42 & [23] Abad 2015 \\
\hline 3595.02 & [23] Abad 2015 \\
\hline 4566.21 & [23] Abad 2015 \\
\hline 2373.60 & [23] Abad 2015 \\
\hline 860.43 & [23] Abad 2015 \\
\hline Cost $(€)$ & Source \\
\hline $47,069.14$ & [24] Villa 2011 \\
\hline $43,997.16$ & [24] Villa 2011 \\
\hline $32,022.17$ & [24] Villa 2011 \\
\hline $29,927.06$ & [24] Villa 2011 \\
\hline $51,677.66$ & [24] Villa 2011 \\
\hline 7280.71 & [24] Villa 2011 \\
\hline Cost $(€)$ & Source \\
\hline 1038.23 & [25] Hammer 2009 \\
\hline 59.07 & [25] Hammer 2009 \\
\hline 3446.53 & Ministry of Health 2012 \\
\hline 5225.52 & Ministry of Health 2012 \\
\hline \multicolumn{2}{|l|}{-} \\
\hline Cost $(€)$ & Source \\
\hline 126.84 & eSalud 2015 (official tariff) \\
\hline 1006.63 & eSalud 2015 (official tariff) \\
\hline 52.32 & Tarifas CCAA 2008. \\
\hline
\end{tabular}


Table 1 Management and complication costs used in the CDM (Continued)

\begin{tabular}{lll}
\hline Blindness - year of onset & 1875.14 & [23] Abad 2015 \\
Blindness - following years & 805.05 & [23] Abad 2015 \\
Direct costs acute events & Cost (€) & Source \\
Neuropathy, 1st year & 4653.06 & [26] Rodríguez 2011 \\
Neuropathy, 2nd + years & 4653.06 & [26] Rodríguez 2011 \\
Amputation (event based) & 3644.47 & [23] Abad 2015 \\
Amputation Prosthesis (event based) & 3712.05 & Estimation \\
Gangrene treatment & $10,131.19$ & eSalud 2015 (official tariff) \\
After healed ulcer & - & \\
Infected ulcer & 5042.78 & eSalud 2015 (official tariff) \\
Standard uninfected ulcer & 1120.96 & eSalud 2015 (official tariff) \\
Healed ulcer history of amputation & - & \\
\hline
\end{tabular}

specific computer simulation model designed to translate surrogate endpoints into long-term health and economic outcomes http://www.core-diabetes.com/.

The CDM includes interdependent sub-models that simulate changes in the rates of microvascular and macrovascular complications and mortality associated with diabetes, for different management strategies. The CDM is populated with demographic data on a cohort of people with diabetes, costs (the 'economic setting'), treatment values for risk factors and adverse events, a treatment algorithm, disease management characteristics and clinical settings. The model structure comprises 17 interdependent sub-models that simulate the complications of diabetes over a time period, in this case, of 25 years. The model is a fixed-time increment (annual) stochastic simulation with each sub-model using time, state, and diabetes-type dependent probabilities. The CDM uses transition probabilities and management strategies Type 2 diabetes, with the predominant sources of data being the UKPDS studies [19]. Table 1 shows the management and complication costs used.

To populate the CDM a representative cohort of patient-level data were drawn from the SIDIAP-Q database of 126,811 people with type 2 diabetes, cared for by the Catalonian Health Institut in 2011 in Catalonia. Although Catalonia may have different demographic characteristics to the rest of Spain, the patients in the SIDIAP-Q database can be considered a typical cohort of people with diabetes cared for in primary care.

SIDIAP (Information System for the Development of Research in Primary Care) is a database of electronic medical records started in 2006 http://www.sidiap.org/ index.php/en. The SIDIAP-Q subpopulation is composed of those people with the most complete medical histories and includes data from 1,878,816 of the 5.8 million patients registered in the parent SIDIAP database.
Methodological details of the study of the cost of type 2 diabetes mellitus using this database have been described in a previous publication [4]. SIDIAP holds longitudinal patient information which is anonymized and drawn from primary care centres in Catalonia using the electronic clinical station for primary care (eCAP). The database includes the medical records of all patients cared for by the Catalan Health Institute and for investigation purposes provides anonymized information on socio-demographic characteristics, health problems using International Classification of Diseases codes (ICD-10), detailed clinical markers, lifestyle measures, diagnostic and clinical procedures, specialist referrals, the results of laboratory and all electronically prescribed treatments. The CatSalut (Catalan National Health Service) general database provides additional data on hospitalization (diagnosis, procedures and length of stay) and the pharmacological treatments actually billed to the CatSalut.

The cohort of people modelled in the CDM was made up of a sample of 10,000 people in the SIDIAP-Q database, selected randomly into four sub-groups of 2500 based on their baseline level of HbA1c: (48 to $\leq 58$ $\mathrm{mmol} / \mathrm{mol}, 58$ to $\leq 64 \mathrm{mmol} / \mathrm{mol} ; 64$ to $\leq 75 \mathrm{mmol} / \mathrm{mol}$; and $>75 \mathrm{mmol} / \mathrm{mol}$ ). Table 2 shows the patient cohort characteristics. For each of the HbA1c groups, estimates of future outcomes were produced using CDM (v9.0) to predict the cumulative incidence of complications for the base case (HbA1c treatment escalations at the current $68 \mathrm{mmol} / \mathrm{mol}$ ) and for the comparator case (HbA1c escalations at $53 \mathrm{mmol} / \mathrm{mol}$ ).

This simulated the effect of a management strategy for type 2 diabetes that intensified or escalated treatment when people reached a threshold of $53 \mathrm{mmol} / \mathrm{mol} \mathrm{com-}$ pared to current practice whereby treatment is intensified at $68 \mathrm{mmol} / \mathrm{mol}$ on average. The effect of each escalation of treatment on the development of complications was modified by the duration of disease and a maximum of five treatment escalations were considered 
Table 2 Patient cohorts characteristics segmented by $\mathrm{HbA} 1 \mathrm{c}$ range

\begin{tabular}{|c|c|c|c|c|c|}
\hline & $\begin{array}{l}\text { All cohorts } \\
(N=10,000)\end{array}$ & $\begin{array}{l}\text { Cohort } 1 \\
48 \text { to } \leq 58 \mathrm{mmol} / \mathrm{mol} \\
(N=2500)\end{array}$ & $\begin{array}{l}\text { Cohort } 2 \\
58 \text { to } \leq 64 \mathrm{mmol} / \mathrm{mol} \\
(N=2500)\end{array}$ & $\begin{array}{l}\text { Cohort } 3 \\
64 \text { to } \leq 75 \mathrm{mmol} / \mathrm{mol} \\
(N=2500)\end{array}$ & $\begin{array}{l}\text { Cohort } \\
4>75 \mathrm{mmol} / \mathrm{mol} \\
(N=2500)\end{array}$ \\
\hline Age [years (SD)] & $68.1(11.5)$ & $68.4(11.6)$ & $69.1(10.8)$ & $68.9(10.9)$ & $65.8(12.2)$ \\
\hline Sex (women) & 4811 (48.1\%) & $1158(46.3 \%)$ & $1250(50.0 \%)$ & $1260(50.4 \%)$ & $1143(45.7 \%)$ \\
\hline Diabetes duration [years (SD)] & $7.33(5.89)$ & $5.97(5.26)$ & $6.56(5.21)$ & $8.07(6.20)$ & $8.73(6.38)$ \\
\hline BMI $\left[\mathrm{kg} / \mathrm{m}^{2}(\mathrm{SD})\right]$ & $30.5(5.18)$ & $30.4(5.12)$ & $30.4(4.92)$ & $30.3(5.35)$ & $30.8(5.30)$ \\
\hline Obesity & $4510(48.2 \%)$ & $1082(46.9 \%)$ & $1141(48.5 \%)$ & 1075 (45.4\%) & $1212(52.0 \%)$ \\
\hline Hypertension & $7102(71.0 \%)$ & $1794(71.8 \%)$ & $1794(71.8 \%)$ & $1842(73.7 \%)$ & $1672(66.9 \%)$ \\
\hline \multicolumn{6}{|l|}{ Smoking habit } \\
\hline Never smoker & 6177 (63.4\%) & $1535(63.7 \%)$ & $1581(64.8 \%)$ & 1594 (64.9\%) & 1467 (60.1\%) \\
\hline Current smoker & $1358(13.9 \%)$ & $323(13.4 \%)$ & $294(12.1 \%)$ & $322(13.1 \%)$ & 419 (17.2\%) \\
\hline Ex-smoker & 2207 (22.7\%) & $551(22.9 \%)$ & $563(23.1 \%)$ & $540(22.0 \%)$ & $553(22.7 \%)$ \\
\hline $\mathrm{SBP}[\mathrm{mmHg}(\mathrm{SD})]$ & $137(13.4)$ & $136(13.3)$ & $136(13.1)$ & $137(12.8)$ & $139(14.0)$ \\
\hline $\mathrm{DBP}[\mathrm{mmHg}(\mathrm{SD})]$ & $76.3(8.42)$ & $75.7(8.43)$ & $76.0(8.11)$ & $76.1(8.29)$ & $77.4(8.76)$ \\
\hline LDL Cholesterol [mg/ml (SD)] & $111(32.8)$ & $112(32.2)$ & $112(32.4)$ & $110(31.0)$ & $113(35.5)$ \\
\hline \multicolumn{6}{|l|}{ Chronic complications } \\
\hline Microalbuminuria & $793(14.1 \%)$ & $144(11.1 \%)$ & $164(11.7 \%)$ & 195 (13.3\%) & $290(20.0 \%)$ \\
\hline Macroalbuminuria & $131(2.33 \%)$ & $24(1.86 \%)$ & $25(1.78 \%)$ & $24(1.64 \%)$ & $58(3.99 \%)$ \\
\hline Chronic renal failure $[(e \mathrm{GFR}<60 \mathrm{ml} / \mathrm{min}(\mathrm{SD})]$ & $1593(18.5 \%)$ & $414(20.2 \%)$ & $401(18.2 \%)$ & $424(19.4 \%)$ & $354(16.3 \%)$ \\
\hline Retinopathy & $751(7.51 \%)$ & $119(4.76 \%)$ & $129(5.16 \%)$ & $203(8.12 \%)$ & $300(12.0 \%)$ \\
\hline Neuropathy & $924(16.5 \%)$ & $168(13.0 \%)$ & 189 (13.4\%) & $219(15.0 \%)$ & $348(24.0 \%)$ \\
\hline Stroke & $764(7.64 \%)$ & $196(7.84 \%)$ & $179(7.16 \%)$ & 199 (7.96\%) & $190(7.60 \%)$ \\
\hline Coronary Heart Disease & $1280(12.8 \%)$ & $301(12.0 \%)$ & $300(12.0 \%)$ & $314(12.6 \%)$ & $365(14.6 \%)$ \\
\hline Heart Failure & $555(5.55 \%)$ & $159(6.36 \%)$ & $110(4.40 \%)$ & $134(5.36 \%)$ & $152(6.08 \%)$ \\
\hline Peripheral arteriopathy & 477 (4.77\%) & 109 (4.36\%) & $95(3.80 \%)$ & $125(5.00 \%)$ & $148(5.92 \%)$ \\
\hline Any macrovascular & $2497(25.0 \%)$ & $619(24.8 \%)$ & $565(22.6 \%)$ & $630(25.2 \%)$ & $683(27.3 \%)$ \\
\hline \multicolumn{6}{|l|}{ Coexistence of complications: } \\
\hline No complications & $6408(64.1 \%)$ & $1698(67.9 \%)$ & $1723(68.9 \%)$ & $1572(62.9 \%)$ & 1415 (56.6\%) \\
\hline only macrovascular & $867(8.67 \%)$ & $250(10.0 \%)$ & $196(7.84 \%)$ & $220(8.80 \%)$ & $201(8.04 \%)$ \\
\hline only microvascular & 1095 (10.9\%) & $183(7.32 \%)$ & $212(8.48 \%)$ & $298(11.9 \%)$ & $402(16.1 \%)$ \\
\hline both & $1630(16.3 \%)$ & $369(14.8 \%)$ & $369(14.8 \%)$ & $410(16.4 \%)$ & $482(19.3 \%)$ \\
\hline \multicolumn{6}{|l|}{ Steps of antidiabetic treatment } \\
\hline Life-style only & $2286(22.9 \%)$ & $1042(41.7 \%)$ & $663(26.5 \%)$ & $358(14.3 \%)$ & $223(8.92 \%)$ \\
\hline Non insulin Antidiabetics & $6015(60.2 \%)$ & $1333(53.3 \%)$ & $1630(65.2 \%)$ & 1693 (67.7\%) & 1359 (54.4\%) \\
\hline Insulin & 1699 (17.0\%) & $125(5.00 \%)$ & $207(8.28 \%)$ & 449 (18.0\%) & 918 (36.7\%) \\
\hline
\end{tabular}

within a 25 year period. It was assumed that each escalation of treatment would be associated with a reduction in HbA1c level by $11 \mathrm{mmol} / \mathrm{mol}$ [27]. The UK Prospective Diabetes Study (UKPDS) recorded a $37 \%$ reduction in microvascular complications for an $11 \mathrm{mmol} / \mathrm{mol} \mathrm{re-}$ duction in HbA1c [28]. No discounting was applied to the costs estimated as this was a budget impact analysis rather than a cost-effectiveness analysis.

Specific forms of treatment that would lead to an $11 \mathrm{mmol} / \mathrm{mol}$ reduction in $\mathrm{HbA} 1 \mathrm{c}$ were not detailed in the analysis because different patients would require different forms of escalation depending on the progression of their disease. The better management strategy should be viewed not as a treatment itself, but rather a collection of activities to encourage people with diabetes and clinicians to maintain or achieve lower HbA1c levels. For those with a higher baseline level of HbA1c, the modelling allowed several successive treatment escalations (up to five times) in order to bring HbA1c levels to target levels. 


\section{Results}

The SIDIAP-Q database includes 126,811 people in the Catalunya region with type 2 diabetes over the age of 30 in 2011. Of the people with a recorded HbA1c level (93, 351), 34.23\% have an HbA1c starting level below 48 $\mathrm{mmol} / \mathrm{mol} ; 34.8 \%$ are between $48 \mathrm{mmol} / \mathrm{mol}$ and 57 $\mathrm{mmol} / \mathrm{mol} ; 10.07 \%$ are between $58 \mathrm{mmol} / \mathrm{mol}$ and 63 $\mathrm{mmol} / \mathrm{mol} ; 10.96 \%$ are between $64 \mathrm{mmol} / \mathrm{mol}$ and 74 $\mathrm{mmol} / \mathrm{mol}$; and $9.94 \%$ are greater than $75 \mathrm{mmol} / \mathrm{mol}$.

The prevalence of known diabetes in Spain is estimated at 7.8\% [29] and the population older than 18 in Spain is 37.2 million [30]. Within the SIDIAP-Q database, $65.77 \%$ of people with a recorded level had HbA1c $>48 \mathrm{mmol} / \mathrm{mol}$. On that basis, we have estimated the adult population of people identified with diabetes and with $\mathrm{HbA} 1 \mathrm{c}>48 \mathrm{mmol} / \mathrm{mol}$ is $1,910,374$. The proportions of people in each of the cohorts in the SIDIAP database were used to estimate the total numbers of people with starting $\mathrm{HbA1c}$ levels in each cohort for the whole of Spain.

The CDM modelling showed that for these cohorts of people with diabetes, if treatment is escalated at HbA1c of $53 \mathrm{mmol} / \mathrm{mol}$ instead of current practice (treatment escalation at $68 \mathrm{mmol} / \mathrm{mol}$ ), the average cost reduction per person varies depending on their baseline HbA1c. After five years, people with starting HbAlc of $>48$ $\mathrm{mmol} / \mathrm{mol}$ to $\leq 58 \mathrm{mmol} / \mathrm{mol}$ show an average cost reduction of $€ 198$, while those with starting HbA1c of > $75 \mathrm{mmol} / \mathrm{mol}$ showed an average cost reduction of $€ 1588$ per person. These increased to $€ 6027$ and $€ 11,966$ per person respectively after 25 years. As mentioned previously, the cost reduction estimates do not include any estimates of the costs of interventions to improve glycaemic control. Table 3 shows the cost reductions per person and for the population.

Applying the per-person cost reduction to the cohorts of the prevalent population gives an overall estimated cost reduction of $€ 14.7$ billion over 25 years. The estimated overall cost reduction rises from $€ 1.3$ billion in year 5 to $€ 5.2$ billion in year 10 , to $€ 9.4$ billion in year 15 and to $€ 12.9$ billion in year 20 .

There is a relatively higher cost reduction in the cohort with starting HbAlc levels of $>48 \mathrm{mmol} / \mathrm{mol}$ to $\leq 58 \mathrm{mmol} / \mathrm{mol}$ after 25 years ( $€ 6.1$ billion) compared to the other cohorts with higher starting HbAlc levels but this may be due to a higher number of people in that cohort. The trajectory of cost reduction reduces between 15 and 25 years in all of the cohorts as the effects of the escalations of treatment in earlier years reduces. Figure 1 shows cumulative cost reduction by starting level of HbA1c.

The improvements in outcomes are demonstrated in an estimated reduction of more than 1.2 million complications cumulatively over 25 years in the intervention group. There is an estimated cumulative reduction in complications of 266,000 after 5 years; 675,000 after 10 years; 974,000 after 15 years and 1.2 million after 20 and 25 years.

More than 550,000 of the avoided complications after 25 years relate to diabetic foot. These include nearly 300 , 000 avoided ulcers and almost 200,000 cases of neuropathy. Around 200,000 complications relating to eye disease would be avoided after 25 years, including 85,000 cases of diabetic retinopathy. 170,000 renal complications would be avoided over 25 year under the scenarios modelled, including around 13,000 cases of end stage renal disease, which has a considerable cost. Around 226,000 CVD events would be avoided over 25 years, including nearly 60,000 myocardial infarctions. Table 4 and Fig. 2 show the cumulative estimated reduction in complications over 25 years.

The modelling also shows that over a 25 -year period, people receiving the intervention would have a longer time alive and free of complications.

\section{Discussion}

This study shows that people with type 2 diabetes in Spain with raised HbA1c levels could gain significant health and economic benefits through improved glycaemic control. By providing people with treatment at a lower recommended HbA1c, on a population basis, significant numbers of diabetes-related microvascular complications can be avoided and related costs can be reduced. Modelling estimates show that in the population of people with type 2 diabetes, more than 1.1 million complications could be prevented over a 25 -year period and more than $€ 14.7$ billion could be saved as a result.

Nearly half of the cost reductions observed in this study are attributable to a reduction in complications of the foot $(553,000)$ in the intervention cohort. There were also significant reductions in eye disease $(204,000)$, renal complications $(171,000)$, and cardiovascular disease $(226$, 000) in the cohort with better glycaemic control.

Similar work carried out by Baxter et al., in the UK setting estimated a lower cumulative 25-year cost saving for type 2 diabetes of around $€ 5.1$ billion, based on people receiving treatment to $\mathrm{HbA1c}$ targets recommended by NICE. In the UK, as in Spain, nearly all of the savings related to reductions in microvascular complications, particularly those for diabetic foot which accounted for around $57 \%$ of the estimated cumulative savings.

The potential cost reductions can be seen as the amount of money which could be spent by the Spanish NHS to achieve the overall improvement in glycaemic control, on a population basis, that could result in the scale of avoided complications demonstrated in this 
Table 3 Cost reductions for avoided complications for the Spanish type 2 diabetes population with starting $\mathrm{HbA} 1 \mathrm{c}>48 \mathrm{mmol} / \mathrm{mol}$

\begin{tabular}{|c|c|c|c|c|c|}
\hline \multicolumn{6}{|c|}{ Adult type 2 diabetes per-person cost reductions } \\
\hline & 5 years & 10 years & 15 years & 20 years & 25 years \\
\hline$>48$ to $\leq 58 \mathrm{mmol} / \mathrm{mol}$ & $€ 198$ & $€ 1754$ & $€ 3653$ & $€ 5221$ & $€ 6027$ \\
\hline 58 to $\leq 64 \mathrm{mmol} / \mathrm{mol}$ & $€ 548$ & $€ 2492$ & $€ 4563$ & $€ 6108$ & $€ 6633$ \\
\hline 64 to $\leq 75 \mathrm{mmol} / \mathrm{mol}$ & $€ 1569$ & $€ 4249$ & $€ 6892$ & $€ 9039$ & $€ 10,233$ \\
\hline$>75 \mathrm{mmol} / \mathrm{mol}$ & $€ 1588$ & $€ 4529$ & $€ 7647$ & $€ 10,369$ & $€ 11,966$ \\
\hline \multicolumn{6}{|c|}{ Adult type 2 diabetes total population cost reductions } \\
\hline & 5 years & 10 years & 15 years & 20 years & 25 years \\
\hline$>48$ to $\leq 58 \mathrm{mmol} / \mathrm{mol}$ & $€ 200,133,593$ & $€ 1,772,900,617$ & $€ 3,692,363,715$ & $€ 5,277,260,048$ & $€ 6,091,945,280$ \\
\hline 58 to $\leq 64 \mathrm{mmol} / \mathrm{mol}$ & $€ 160,234,152$ & $€ 728,656,033$ & $€ 1,334,212,472$ & $€ 1,785,967,517$ & $€ 1,939,476,513$ \\
\hline 64 to $\leq 75 \mathrm{mmol} / \mathrm{mol}$ & $€ 499,489,460$ & $€ 1,352,664,574$ & $€ 2,194,060,778$ & $€ 2,877,555,916$ & $€ 3,257,664,530$ \\
\hline$>75 \mathrm{mmol} / \mathrm{mol}$ & $€ 458,695,151$ & $€ 1,308,205,503$ & $€ 2,208,842,455$ & $€ 2,995,094,470$ & $€ 3,456,389,279$ \\
\hline TOTAL & $€ 1.319$ bn & $€ 5.162$ bn & $€ 9.429$ bn & $€ 12.936$ bn & $€ 14.745$ bn \\
\hline
\end{tabular}

study. This does not specify the types of intervention programme that should be adopted, and the way in which the money is spent and the interventions which could be employed to improve glycaemic control will be at the discretion of local health care commissioners.

The types of intervention applicable for individual people will depend on a number of factors and some interventions may have minimal cost. The Spanish primary care RedGDPS algorithm for blood glucose lowering therapy in adults with type 2 diabetes recommends the use of metformin as an initial intervention followed by dual therapy (metformin plus either dipeptidyl peptidase-4 inhibitor, glucagon-like peptide-1, sodiumglucose cotransporter 2 inhibitors or sulfonylurea) and then triple therapy (metformin plus combinations of other therapies), before progression to insulin-based treatment [11]. There will be many variations in the therapies used and associated costs based on the individual requirements of people with type 2 diabetes. The key point is that treatment escalation needs to happen more quickly at the point at which individual people reach the $\mathrm{HbA} 1 \mathrm{c}$ threshold of $53 \mathrm{mmol} / \mathrm{mol}$.

The study does though set out the amount of money that could be used in order to achieve improved levels of glycaemic control. It also shows, importantly, that benefits in terms of numbers of complications avoided, and costs saved as a result of reduced numbers of events, are accrued as soon as five years after better control has been achieved. Although there is a slower trajectory for benefits in earlier years, there is much more rapid benefit gain between years 5 and 15 .

It is important to note the limitations of this study:

- The study does not include the costs associated with implementing strategies to improve glycaemic control on a population or individual

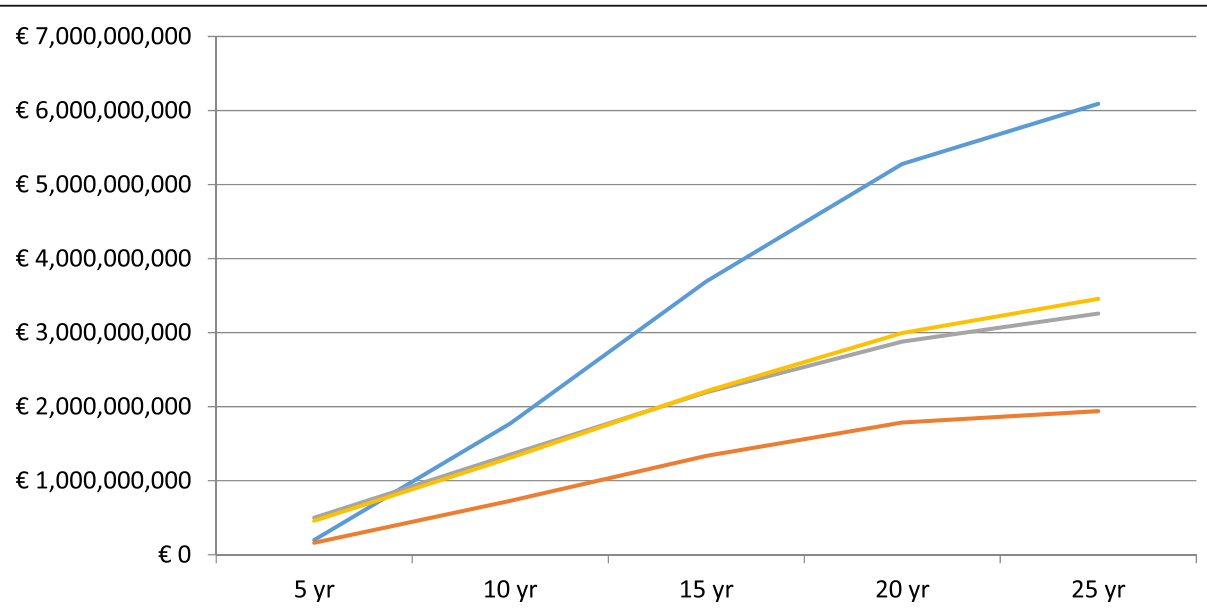

Fig. 1 Cumulative cost reduction for the Spanish type 2 diabetes population with starting HbA1c $>48 \mathrm{mmol} / \mathrm{mol}$. Blue $=>48$ to $\leq 58 \mathrm{mmol} / \mathrm{mol}$. Red $=58$ to $\leq 64 \mathrm{mmol} / \mathrm{mol}$. Grey $=64$ to $\leq 75 \mathrm{mmol} / \mathrm{mol}$. Yellow $=>75 \mathrm{mmol} / \mathrm{mol}$ 
Table 4 Reduced incidence of complications for the Spanish type 2 diabetes population with starting HbA1c $>48 \mathrm{mmol} / \mathrm{mol}$ (per 1000 population)

\begin{tabular}{|c|c|c|c|c|c|}
\hline$>48$ to $\leq 58 \mathrm{mmol} / \mathrm{mol}$ & 5 years & 10 years & 15 years & 20 years & 25 years \\
\hline \multicolumn{6}{|l|}{ Eye disease } \\
\hline BDR & 5.5 & 22.8 & 33.1 & 38.8 & 36.0 \\
\hline PDR & 0.3 & 1.7 & 3.0 & 3.9 & 4.1 \\
\hline ME & 5.1 & 20.7 & 30.7 & 36.0 & 33.5 \\
\hline SVL & 0.1 & 2.4 & 5.7 & 8.7 & 10.6 \\
\hline Cataract & 1.8 & 6.3 & 8.8 & 10.2 & 9.3 \\
\hline TOTAL & 12.7 & 54.0 & 81.3 & 97.6 & 93.5 \\
\hline \multicolumn{6}{|l|}{ Renal disease } \\
\hline MA & 8.0 & 31.0 & 45.0 & 52.0 & 47.3 \\
\hline GRP & 1.3 & 7.7 & 13.9 & 19.0 & 19.2 \\
\hline ESRD & 0.2 & 1.4 & 2.9 & 4.5 & 5.3 \\
\hline TOTAL & 9.5 & 40.1 & 61.9 & 75.5 & 71.8 \\
\hline \multicolumn{6}{|l|}{ Diabetic foot } \\
\hline Ulcer & 3.5 & 23.2 & 42.0 & 53.5 & 52.9 \\
\hline Recurrent ulcer & 0.5 & 9.1 & 30.7 & 56.0 & 75.0 \\
\hline Amputation ulcer & 0.2 & 3.2 & 8.9 & 14.5 & 17.8 \\
\hline Amputation recurrent ulcer & 0 & 0.4 & 1.6 & 3.5 & 5.3 \\
\hline Neuropathy & 26.8 & 85.6 & 106.9 & 110.1 & 94.5 \\
\hline TOTAL & 31.0 & 121.6 & 190.2 & 237.5 & 245.4 \\
\hline \multicolumn{6}{|l|}{ Cardiovascular disease } \\
\hline CHF onset & 0.5 & 5.2 & 7.7 & 8.8 & 8.4 \\
\hline PVD onset & 2.4 & 9.2 & 13.7 & 16.5 & 15.5 \\
\hline Angina & 0.5 & 6.0 & 9.0 & 10.1 & 9.7 \\
\hline Diabetes mortality & 0 & 0.9 & 3.0 & 5.7 & 8.0 \\
\hline Stroke event & -0.1 & 4.9 & 6.8 & 7.2 & 6.5 \\
\hline Event fatality & 1.4 & 17.4 & 27.8 & 32.7 & 32.9 \\
\hline Ml event & 0.9 & 16.7 & 26.8 & 31.3 & 31.3 \\
\hline TOTAL & 5.7 & 59.7 & 94.8 & 112.3 & 112.2 \\
\hline 58 to $\leq 64 \mathrm{mmol} / \mathrm{mol}$ & 5 years & 10 years & 15 years & 20 years & 25 years \\
\hline \multicolumn{6}{|l|}{ Eye disease } \\
\hline BDR & 3.4 & 8.0 & 10.9 & 11.4 & 9.5 \\
\hline PDR & 0.3 & 0.8 & 1.3 & 1.5 & 1.3 \\
\hline ME & 3.1 & 7.7 & 10.6 & 11.2 & 9.3 \\
\hline SVL & 0.1 & 1.1 & 2.2 & 3.1 & 3.4 \\
\hline Cataract & 0.9 & 2.1 & 2.8 & 2.9 & 2.5 \\
\hline TOTAL & 7.8 & 19.7 & 27.7 & 30.01 & 26.1 \\
\hline \multicolumn{6}{|l|}{ Renal disease } \\
\hline MA & 4.6 & 11.2 & 15.2 & 15.7 & 12.6 \\
\hline GRP & 0.9 & 3.1 & 5.1 & 6.3 & 5.5 \\
\hline ESRD & 0.1 & 0.6 & 1.1 & 1.5 & 1.5 \\
\hline TOTAL & 5.7 & 14.8 & 21.5 & 23.5 & 19.6 \\
\hline \multicolumn{6}{|l|}{ Diabetic foot } \\
\hline Ulcer & 2.4 & 8.9 & 14.5 & 16.7 & 15.4 \\
\hline
\end{tabular}


Table 4 Reduced incidence of complications for the Spanish type 2 diabetes population with starting HbA1c $>48 \mathrm{mmol} / \mathrm{mol}$ (per 1000 population) (Continued)

\begin{tabular}{|c|c|c|c|c|c|}
\hline Recurrent ulcer & 0.4 & 4.5 & 12.0 & 19.9 & 24.7 \\
\hline Amputation ulcer & 0.2 & 1.5 & 3.3 & 5.0 & 5.6 \\
\hline Amputation recurrent ulcer & 0 & 0.2 & 0.7 & 1.3 & 1.9 \\
\hline Neuropathy & 14.7 & 29.4 & 34.7 & 32.3 & 26.4 \\
\hline TOTAL & 17.7 & 44.5 & 65.02 & 75.2 & 74.0 \\
\hline \multicolumn{6}{|l|}{ Cardiovascular disease } \\
\hline CHF onset & 0.5 & 1.8 & 2.4 & 2.5 & 2.0 \\
\hline PVD onset & 1.3 & 3.1 & 4.4 & 4.5 & 3.8 \\
\hline Angina & 0.5 & 2.0 & 2.8 & 2.8 & 2.4 \\
\hline Diabetes mortality & 0 & 0.4 & 1.0 & 1.7 & 2.4 \\
\hline Stroke event & 0.4 & 1.7 & 2.1 & 2.1 & 1.7 \\
\hline Event fatality & 1.6 & 6.3 & 8.7 & 9.5 & 8.6 \\
\hline Ml event & 1.6 & 6.2 & 8.4 & 8.9 & 8.2 \\
\hline TOTAL & 6.0 & 21.6 & 29.9 & 32.1 & 29.2 \\
\hline 64 to $\leq 75 \mathrm{mmol} / \mathrm{mol}$ & 5 years & 10 years & 15 years & 20 years & 25 years \\
\hline \multicolumn{6}{|l|}{ Eye disease } \\
\hline BDR & 6.9 & 11.5 & 14.5 & 16.3 & 15.4 \\
\hline PDR & 0.7 & 1.3 & 1.9 & 2.3 & 2.3 \\
\hline ME & 6.7 & 11.4 & 14.6 & 16.5 & 15.7 \\
\hline SVL & 0.6 & 1.9 & 3.4 & 4.8 & 5.6 \\
\hline Cataract & 1.9 & 3.2 & 3.9 & 4.4 & 4.1 \\
\hline TOTAL & 16.9 & 29.3 & 38.4 & 44.2 & 43.1 \\
\hline \multicolumn{6}{|l|}{ Renal disease } \\
\hline MA & 9.8 & 16.2 & 20.4 & 22.8 & 21.2 \\
\hline GRP & 2.3 & 4.8 & 7.3 & 9.4 & 9.7 \\
\hline ESRD & 0.4 & 1.1 & 1.8 & 2.5 & 2.9 \\
\hline TOTAL & 12.5 & 22.1 & 29.5 & 34.7 & 33.8 \\
\hline \multicolumn{6}{|l|}{ Diabetic foot } \\
\hline Ulcer & 5.9 & 14.3 & 20.9 & 24.8 & 24.6 \\
\hline Recurrent ulcer & 1.6 & 8.9 & 20.1 & 31.3 & 39.5 \\
\hline Amputation ulcer & 0.7 & 2.7 & 5.3 & 7.6 & 9.1 \\
\hline Amputation recurrent ulcer & 0.1 & 0.5 & 1.3 & 2.3 & 3.4 \\
\hline Neuropathy & 31.0 & 43.2 & 47.2 & 47.2 & 41.1 \\
\hline TOTAL & 39.3 & 69.6 & 94.7 & 113.3 & 117.8 \\
\hline \multicolumn{6}{|l|}{ Cardiovascular disease } \\
\hline CHF onset & 1.9 & 3.0 & 3.6 & 3,8 & 3.6 \\
\hline PVD onset & 2.4 & 4.3 & 5.7 & 6.6 & 6.2 \\
\hline Angina & 2.1 & 3.3 & 4.0 & 4.3 & 4.0 \\
\hline Diabetes mortality & 0.2 & 0.7 & 1.7 & 2.7 & 3.8 \\
\hline Stroke event & 1.8 & 2.7 & 3.0 & 3.1 & 2.9 \\
\hline Event fatality & 5.6 & 9.5 & 11.6 & 12.7 & 12.5 \\
\hline Ml event & 5.2 & 8.7 & 10.4 & 11.2 & 10.8 \\
\hline TOTAL & 19.1 & 32.2 & 40.0 & 44.4 & 43.8 \\
\hline$>75 \mathrm{mmol} / \mathrm{mol}$ & 5 years & 10 years & 15 years & 20 years & 25 years \\
\hline
\end{tabular}


Table 4 Reduced incidence of complications for the Spanish type 2 diabetes population with starting HbA1c $>48 \mathrm{mmol} / \mathrm{mol}$ (per 1000 population) (Continued)

\begin{tabular}{|c|c|c|c|c|c|}
\hline \multicolumn{6}{|l|}{ Eye disease } \\
\hline BDR & 6.5 & 10.7 & 13.8 & 15.7 & 14.6 \\
\hline PDR & 0.7 & 1.3 & 1.8 & 2.3 & 2.3 \\
\hline ME & 6.4 & 10.6 & 13.8 & 15.9 & 14.9 \\
\hline SVL & 0.5 & 1.9 & 3.4 & 4.9 & 5.7 \\
\hline Cataract & 1.8 & 2.9 & 3.7 & 4.2 & 3.9 \\
\hline TOTAL & 15.8 & 27.3 & 36.6 & 43.1 & 41.4 \\
\hline \multicolumn{6}{|l|}{ Renal disease } \\
\hline MA & 8.9 & 14.7 & 18.8 & 21.3 & 19.4 \\
\hline GRP & 5.1 & 10.0 & 14.9 & 19.3 & 22.9 \\
\hline ESRD & 0.5 & 1.2 & 2.1 & 3.0 & 3.4 \\
\hline TOTAL & 14.5 & 25.9 & 35.8 & 43.5 & 45.6 \\
\hline \multicolumn{6}{|l|}{ Diabetic foot } \\
\hline Ulcer & 5.6 & 13.5 & 20.2 & 24.5 & 24.1 \\
\hline Recurrent ulcer & 1.4 & 8.4 & 19.8 & 32.0 & 41.3 \\
\hline Amputation ulcer & 0.6 & 2.6 & 5.2 & 7.7 & 9.4 \\
\hline Amputation recurrent ulcer & 0.1 & 0.4 & 1.3 & 2.5 & 3.7 \\
\hline Neuropathy & 28.5 & 39.7 & 43.7 & 43.8 & 37.0 \\
\hline TOTAL & 36.0 & 64.6 & 90.2 & 110.5 & 115.5 \\
\hline \multicolumn{6}{|l|}{ Cardiovascular disease } \\
\hline CHF onset & 1.5 & 2.4 & 3.0 & 3.2 & 2.9 \\
\hline PVD onset & 2.1 & 3.8 & 5.3 & 6.4 & 5.9 \\
\hline Angina & 1.9 & 3.3 & 4.0 & 4.5 & 4.1 \\
\hline Diabetes mortality & 0 & 0.5 & 1.6 & 2.8 & 4.2 \\
\hline Stroke event & 1.4 & 2.4 & 2.8 & 2.9 & 2.7 \\
\hline Event fatality & 4.5 & 8.1 & 10.1 & 11.4 & 11.1 \\
\hline Ml event & 4.4 & 7.7 & 9.6 & 10.5 & 10.0 \\
\hline TOTAL & 15.8 & 28.3 & 36.4 & 41.6 & 41.0 \\
\hline
\end{tabular}

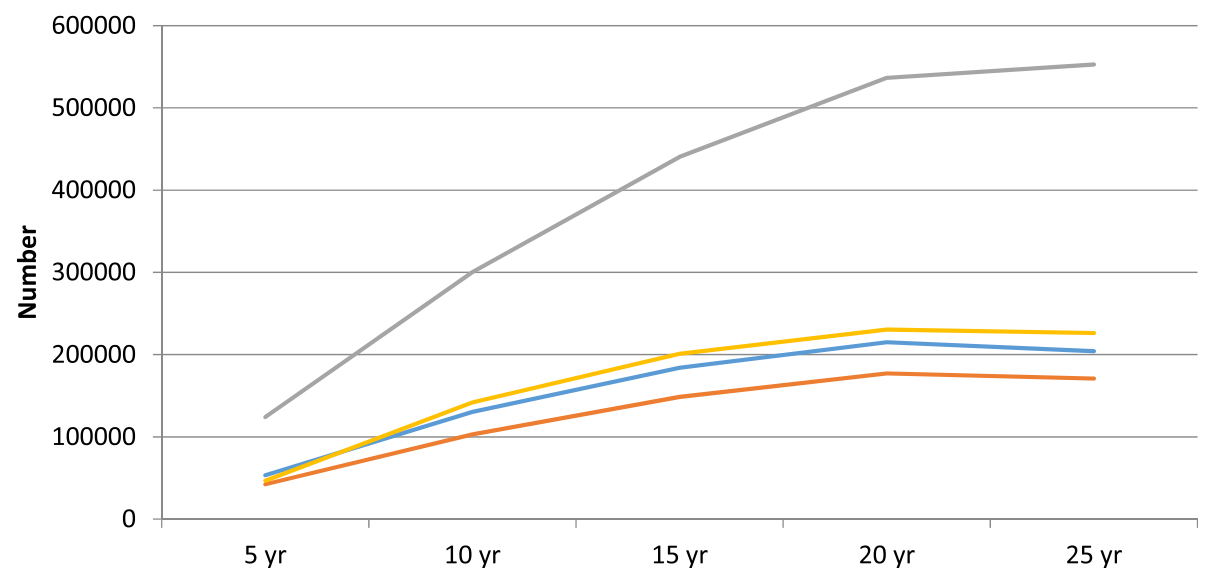

Fig. 2 Cumulative reduction of types of complication for the Spanish type 2 diabetes population with starting $\mathrm{HbA} 1 \mathrm{c}>48 \mathrm{mmol} / \mathrm{mol}$. Blue = Eyes. Red $=$ Renal. Grey $=$ Feet. Yellow $=$ CVD 
level. There are a broad number of potential interventions that could be used but these will vary dependent on population characteristics and local treatment protocols and infrastructure. Local providers are best placed to determine the optimal use of different interventions for people with type 2 diabetes.

- The sample population used in the economic model are drawn from one area of Spain (Catalonia) but can be considered to be typical primary care patients.

- The study does not take into account any increase in the population with type 2 diabetes. Diabetes prevalence is likely to increase in future years and so, again, these cost reductions may be a relatively conservative estimate.

- Quality adjusted life years have not been considered as this is a budget impact analysis rather than a cost-effectiveness analysis. For the same reason, the future cost reductions have not been discounted by any factor.

- The study does not consider the improvements in quality of life experienced by the intervention group through the avoidance of complications.

- Although the study is based on a validated diabetes model (CDM) predominantly based on the UKPDS studies, it is recognised that management strategies for diabetes may have changed over time.

\section{Conclusions}

Over a 25 year period, Spain could considerably reduce costs and avoid major complications if, on a population level, more ambitious glycaemic control, according to Spanish or EU guidelines, could be achieved among people with type 2 diabetes by reducing the HbA1c threshold for treatment intensification. Although there is a slower trajectory for benefits in earlier years, there is much more rapid benefit gain between years 5 and 15 .

\section{Abbreviations}

BDR: Background diabetic retinopathy; CDM: Core Diabetes Model; CHF: Chronic heart failure; GRP: Gross Renal Proteinuria; mmol/ mol: Millimoles per mole; MA: Metabolic acidosis; ME: Macular edema; MI: Myocardial infarction; NHS: National Health Service; NICE: National Institute of Health and Care Excellence; PDR: Proliferative diabetic retinopathy; PVD: Peripheral vascular disease; SVL: Severe vision loss; UKPDS: UK Prospective Diabetes Study

\section{Acknowledgements}

An abstract including high level results from the study reported in a poster as the ISPOR Europe meeting in 2018 was published in Value in Health: Mata-Cases M, et al. PDB51 Results of the Cosmodia study: Estimating the impact on the number of clinical complications and the associated potential financial benefit as a consequence of better management of glycaemic control in people with type 2 diabetes in Spain. Value in Health 21(3), S126.

\section{Authors' contributions}

MMC, DM, JF-M and JR conceived and helped to design the study, acquired and provided data, provided expert guidance on interpretation of data and drafted elements of the manuscript. JM and NH conceived and helped design the study, analysed and interpreted the data and drafted the manuscript. All authors have read and approved the manuscript.

\section{Funding}

The funding for the study came from the IDIAP Jordi Gol and an unrestricted grant provided by Sanofi. Sanofi had no role in the design of the study, collection, analysis and interpretation of data, and had no involvement in writing the manuscript.

\section{Availability of data and materials}

The datasets generated and analysed during the current study are not publicly available due to the fact that they were analysed using the IQVIA Core Diabetes Model but are available from the corresponding author on reasonable request. The database used was http://www.core-diabetes.com/ login.asp and this is a closed database which YHEC received permission to access and use for a temporary time period.

Ethics approval and consent to participate

Not applicable.

\section{Consent for publication}

Not applicable.

\section{Competing interests}

ICMJE Form for Disclosure of Conflicts of Interest.

Dr. Mata-Cases reports personal fees from SANOFI, during the conduct of the study; personal fees from ASTRA ZENECA, BYER, BOEHRINGER INGELHEIM, ELI LILLY, GLAXO SMITHKLINE FERRER, KERN PHARMA, MSD, MENARINI, NOVARTIS, personal fees from NOVONORDISK, SANOFI, outside the submitted work; Mr. Mahon reports grants from SANOFI, during the conduct of the study; Dr. Mauricio reports personal fees from SANOFI, during the conduct of the study; personal fees from ASTRA ZENECA, BOEHRINGER INGELHEIM, ELI LILLY, FERRER, GLAXO SMITHKLINE, JANSSEN, MENARINI, MERCK SHARP \& DOHME, NOVARTIS, NOVONORDISK, SANOFI, outside the submitted work;

Dr. Franch-Nadal reports personal fees from SANOFI, during the conduct of the study; personal fees from ASTRA ZENECA, BOEHRINGER INGELHEIM, ELI LILLY, FERRER, GLAXO SMITHKLINE, JANSSEN, MENARINI, MERCK SHARP \& DOHME, NOVARTIS, NOVONORDISK, SANOFI, outside the submitted work Dr. Real has nothing to disclose;

Mr. Hex reports grants from SANOFI, during the conduct of the study. All authors have read and approved the manuscript.

\section{Author details}

${ }^{1}$ DAP-Cat group, Unitat de Suport a la Recerca Barcelona Ciutat, Institut Universitari d'Investigació en Atenció Primària Jordi Gol (IDIAP Jordi Gol), CIBER of Diabetes and Associated Metabolic Diseases (CIBERDEM), Instituto de Salud Carlos III (ISCIII), Carrer Sardenya 375, entlo 1a, 08025 Barcelona, Spain. ${ }^{2}$ York Health Economics Consortium Ltd, University of York, York, UK.

Received: 1 July 2019 Accepted: 24 May 2020

Published online: 26 August 2020

\section{References}

1. Li R, Bilik D, Brown MB, Zhang P, Ettner SL, Ackermann RT, Crosson JC, Herman WH. Medical costs associated with type 2 diabetes complications and comorbidities. Am J Manag Care. 2013:19(5):421-30. 23781894.

2. Wirehn AB, Andersson A, Ostgren CJ, Carstensen J. Age specific direct healthcare costs attributable to diabetes in a Swedish population: a registerbased analysis. Diabet Med. 2008;25(6):732-7.

3. Bruno G, Picariello R, Petrelli A, Panero F, Costa G, Cavallo-Perin P, Demaria M, Gnavi R. Direct costs in diabetic and non diabetic people: the population-based Turin study, Italy. Nutr Metab Cardiovasc Dis. 2012;22(8): 684-90

4. Mata-Cases M, Casajuana M, Franch-Nadal J, Casellas A, Castell C, Vinagre I, Mauricio D, Bolíbar B. Direct medical costs attributable to type 2 diabetes mellitus: a population-based study in Catalonia, Spain. Eur J Health Econ.; 17(8):1001-1010 (2016). Epub 2015 Nov 5. PMID: 26542160 DOl: https://doi. org/10.1007/s10198-015-0742-5. 
5. Ariza MA, Vimalananda VG, Rosenzweig JL. The economic consequences of diabetes and cardiovascular disease in the United States. Rev Endocr Metab Disord. 2010;11(1):1-10.

6. Vinagre I, Mata-Cases M, Hermosilla E, Morros R, Fina F, Rosell M, Castell C, Franch-Nadal J, Bolibar B, Mauricio D. Control of glycemia and cardiovascular risk factors in patients with type 2 diabetes in primary care in Catalonia (Spain). Diabetes Care. 2012;35(4):774-9.

7. Mata-Cases M, Benito-Badorrey B, Roura-Olmeda P, Franch-Nadal J, PepióVilaubí JM, Saez M, Coll-de-Tuero G, GEDAPS (Primary Care Group for the study of Diabetes) of the Catalonian Society of Family and Community Medicine. Clinical inertia in the treatment of hyperglycemia in type 2 diabetes patients in primary care. Curr Med Res Opin. 2013;29:1495-502.

8. Mata-Cases M, Franch-Nadal J, Real J, Mauricio D. Glycaemic control and antidiabetic treatment trends in primary care centres in patients with type 2 diabetes mellitus during 2007-2013 in Catalonia: a population-based study. BMJ Open. 2016;6(10):e012463.

9. Conthe P, Mata M, Orozco D, Pajuelo F, Barreto CS, Fernández-Anaya S, et al. Degree of control and delayed intensification of antihyperglycaemic treatment in type 2 diabetes mellitus patients in primary care in Spain. Diabetes Res Clin Pract. 2011;91(1):108-14.

10. Mata-Cases M, Franch-Nadal J, Real J, Gratacòs M, López-Simarro F, Khunti K, Mauricio D. Therapeutic Inertia in Patients Treated With Two or More Antidiabetics in Primary Care: Factors Predicting Intensification of Treatment. Diabetes Obes Metab. 2018;20(1):103-112. doi: https://doi.org/10.1111/dom. 13045. Epub 2017 Jul 28. PMID: 28656746 DOl: https://doi.org/10.1111/dom. 13045.

11. Artola MS. Actualización del algoritmo de hiperglucemia de la Red de Grupos de Estudio de Diabetes en Atención Primaria de la Salud 2017 (redGDPS). Diabetes Práctica. 2017;08(02):49-96. https://doi.org/10.26322/ 2013.7923.1500970425.03.

12. The Task Force on diabetes, pre-diabetes, and cardiovascular diseases of The European Society of Cardiology (ESC) and developed in collaboration with the European Association for the Study of Diabetes (EASD). ESC Guidelines on diabetes, pre-diabetes, and cardiovascular diseases developed in collaboration with the EASD. Eur Heart J. 2013;34:3035-87. https://doi. org/10.1093/eurheartj/eht108.

13. Lopez-Simarro F, Brotons C, Moral I, et al. Inertia and treatment compliance in patients with type 2 diabetes in primary care. Med Clin (Barc). 2012;138(9):37784. https://doi.org/10.1016/j.medcli.2011.07.023 Epub 2011 Oct 28.

14. Gonzalez-Clemente JM, Font B, Lahoz R, Llaurado G, Gambus G, Grupo de investigadores del Estudio INERCIA. INERTIA study: Clinical inertia in noninsulinized patients on oral hypoglycemic treatment. A study in Spanish primary and specialty care settings. Med Clin (Barc). 2014 ;142(11):478-484 doi: https://doi.org/10.1016/j.medcli.2013.02.032. Epub 2013 Apr 23.

15. Khunti K, Wolden ML, Thorsted BL, Andersen M, Davies MJ. Clinical inertia in people with type 2 diabetes: a retrospective cohort study of more than 80,000 people. Diabetes Care. 2013;36:3411-7.

16. Mata-Cases M, Franch-Nadal J, Mauricio D, Bolíbar B. Research in diabetes from a primary care database: the information system development research in primary care (SIDIAP) experience. AvDiabetol. 2013;29(6):169-74. https://doi.org/10.1016/j.avdiab.2013.09.002.

17. Baxter M, Hudson R, Mahon J, Bartlett C, Samyshkin Y, Alexiou D, Hex N. Estimating the impact of better glycaemic control in adults with type 1 and type 2 diabetes on the number of clinical complications and the associated financial benefit. Diabet Med. 2016:33(11):1575-81.

18. UK National Institute for Health and Care Excellence (2015). Type 2 diabetes in adults: management. (NICE guideline NG28).

19. McEwan P, Foos V, Palmer JL, Lamotte M, Lloyd A, Grant D. Validation of the IMS CORE diabetes model. Value Health. 2014 Sep;17(6):714-24.

20. Editorials, Computer Modeling of Diabetes and Its Complications. A Report on the Fifth Mount Hood Challenge Meeting, Value in Health, vol. 16; 2013. p. 453-4.

21. Fonseca T, Clegg J, Caputo G, Norrbacka K, Dilla T, Alvarez M. The costeffectiveness of exenatide once weekly compared with exenatide twice daily and insulin glargine for the treatment of patients with type two diabetes and body mass index $\geq 30 \mathrm{~kg} / \mathrm{m}$ (2) in Spain. J Med Econ. 2013; 16(7):926-38.

22. Generalitat de Catalunya, Departyament de Salut (2011). Estudio de costes y carga de la depresión en Cataluña (CostDep-2006).

23. Abad Paniagua EJ, Casado Escribano P, Fernández Rodriguez JM, Morales Escobar FJ, Betegón Nicolás L, Sánchez-Covisa J, Brosa M. Análisis de costeefectividad de dapagliflozina en comparación con los inhibidores de la
DPP4 y otros antidiabéticos orales en el tratamiento de la diabetes mellitus tipo 2 en España. Aten Primaria. 2015;47(8):505-13.

24. Villa G, Rodríguez-Carmona A, Fernández-Ortiz L, Cuervo J, Rebollo P, Otero A, Arrieta J. Cost analysis of the Spanish renal replacement therapy programme. Nephrol Dial Transplant. 2011;26(11):3709-14.

25. Hammer M, Lammert M, Mejías SM, Kern W, Frier BM. Costs of managing severe hypoglycaemia in three European countries. J Med Econ. 2009;12(4): 281-90.

26. Rodríguez A, Calle A, Vázquez L, Chacón F, Polavieja P, Reviriego J. Blood glucose control and quality of health care in non-insulin-treated patients with type 2 diabetes in Spain: a retrospective and cross-sectional observational study. Diabet Med. 2011;28:731-40.

27. Najafipour F, Mobasseri M, Yavari A, Nadrian H, Aliasgarzadeh A, Mashinchi Abbasi N, Niafar M, Houshyar Gharamaleki J, Sadra V. Effect of regular exercise training on changes in $\mathrm{HbA} 1 \mathrm{c}, \mathrm{BMI}$ and $\mathrm{VO} 2$ max among patients with type 2 diabetes mellitus: and 8-year trial. BMJ Open Diabetes Res Care. 2017;5(1):e000414.

28. UK Prospective Diabetes Study (UKPDS) Group. Intensive blood-glucose control with sulphonylureas or insulin compared with conventional treatment and risk of complications in patients with type 2 diabetes (UKPDS 33). Lancet. 1998:352:837-51.

29. Soriguer F, Goday A, Bosch-Comas A, Bordiú E, Calle-Pascual A, et al. Prevalence of diabetes mellitus and impaired glucose regulation in Spain: The Di@bet.es study. Diabetologia. 2012;55(1):88-93.

30. World Bank. http://data.worldbank.org/indicator/SP.POP.TOTL.

\section{Publisher's Note}

Springer Nature remains neutral with regard to jurisdictional claims in published maps and institutional affiliations.
Ready to submit your research? Choose BMC and benefit from:

- fast, convenient online submission

- thorough peer review by experienced researchers in your field

- rapid publication on acceptance

- support for research data, including large and complex data types

- gold Open Access which fosters wider collaboration and increased citations

- maximum visibility for your research: over $100 \mathrm{M}$ website views per year

At BMC, research is always in progress.

Learn more biomedcentral.com/submissions 